(

\title{
Sexual dimorphism in cortisol metabolism throughout pubertal development: a longitudinal study
}

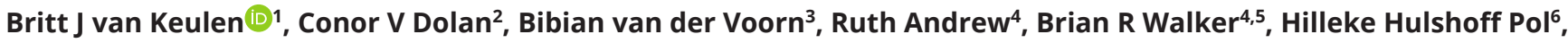 \\ Dorret I Boomsma ${ }^{2}$, Joost Rotteveel ${ }^{1}$ and Martijn J J Finken ${ }^{1}$ \\ ${ }^{1}$ Emma Children's Hospital, Amsterdam UMC, Vrije Universiteit Amsterdam, Pediatric Endocrinology, Amsterdam, The Netherlands \\ ${ }^{2}$ Department of Biological Psychology, Vrije Universiteit Amsterdam, Amsterdam, The Netherlands \\ ${ }^{3}$ Department of Pediatric Endocrinology, Sophia Kinderziekenhuis, Erasmus MC, University Medical Center Rotterdam, Rotterdam, The Netherlands \\ ${ }^{4}$ Centre for Cardiovascular Science, University of Edinburgh, Queen's Medical Research Institute, Edinburgh, UK \\ 5 Institute of Genetic Medicine, Newcastle University, Newcastle upon Tyne, UK \\ ${ }^{6}$ Department of Psychiatry, Brain Center Rudolf Magnus, University Medical Center Utrecht, Utrecht, The Netherlands
}

Correspondence should be addressed to B J van Keulen: b.j.vankeulen@amsterdamumc.nI

\begin{abstract}
Objective: Sex differences in disease susceptibility might be explained by sexual dimorphism in hypothalamic-pituitary-adrenal axis activity, which has been postulated to emerge during puberty. However, studies conducted thus far lacked an assessment of Tanner pubertal stage. This study aimed to assess the contribution of pubertal development to sexual dimorphism in cortisol production and metabolism.

Methods: Participants $(n=218)$ were enrolled from a population-based Netherlands Twin Register. At the ages of 9, 12 and 17 years, Tanner pubertal stage was assessed and early morning urine samples were collected. Cortisol metabolites were measured with GC-MS/MS and ratios were calculated, representing cortisol metabolism enzyme activities, such as A-ring reductases, $11 \beta$-HSDs and CYP3A4. Cortisol production and metabolism parameters were compared between sexes for pre-pubertal (Tanner stage 1), early pubertal (Tanner stage 2-3) and late-pubertal (Tanner stage 4-5) stages. Results: Cortisol metabolite excretion rate decreased with pubertal maturation in both sexes, but did not significantly differ between sexes at any pubertal stage, although in girls a considerable decrease was observed between early and late-pubertal stage $(P<0.001)$. A-ring reductase activity was similar between sexes at pre- and early pubertal stages and was lower in girls than in boys at late-pubertal stage. Activities of $11 \beta$-HSDs were similar between sexes at pre-pubertal stage and favored cortisone in girls at early and late-pubertal stages. Cytochrome P450 3A4 activity did not differ between sexes. Conclusions: Prepubertally, sexes were similar in cortisol parameters. During puberty, as compared to boys, in girls the activities of A-ring reductases declined and the balance between $11 \beta$-HSDs progressively favored cortisone. In addition, girls showed a considerable decrease in cortisol metabolite excretion rate between early and latepubertal stages. Our findings suggest that the sexual dimorphism in cortisol may either be explained by rising concentrations of sex steroids or by puberty-induced changes in body composition.
\end{abstract}

\author{
Key Words \\ - glucocorticoid \\ - metabolites \\ - steroid \\ - Tanner \\ - sex differences
}

Endocrine Connections (2020) 9, 542-551 


\section{Introduction}

Males and females differ in their susceptibility to develop specific diseases. While females are more likely to develop auto-immune diseases and neuropsychiatric disorders like anxiety and depression, males are more susceptible to infectious diseases and are more likely to engage in violent competition $(1,2,3)$. Moreover, males and females differ in cardiovascular disease susceptibility (4). Sex differences in HPA-axis settings have been hypothesized to play a role in these differences $(5,6,7,8,9,10)$.

Sexual dimorphism in HPA-axis activity has been suggested to be already present in early childhood. A recent meta-analysis suggested that boys and girls differed in basal HPA-axis activity, as assessed by salivary cortisol levels. Compared to girls, boys, up to age 8 , had higher salivary cortisol levels and lower levels beyond this age (11). The timing of this change suggests that sex steroids influence the HPA axis. Surprisingly, to the best of our knowledge, there are no studies that have reported on HPA-axis activity across pubertal development.

HPA-axis activity is determined by the net effect of cortisol production and metabolism. Cortisol is metabolized by various enzymes (Fig. 1). The A-ring reductases $(5 \alpha-$ and $5 \beta$-reductase), together with cytochrome P (CYP) 3A4, eliminate cortisol from the circulation primarily in the liver (12). The 11betahydroxysteroid dehydrogenase (11/-HSD) isozymes regulate the interconversion between cortisol and its inactive metabolite cortisone. $11 \beta$-HSD type 1 is mainly expressed in the liver and adipose tissue, where it regenerates cortisol, and $11 \beta$-HSD type 2 catalyzes the reverse reaction in renal epithelial cells.

In adulthood, females were found to have a lower urinary excretion rate of cortisol metabolites than males $(13,14,15)$. This is likely to be attributed to less A-ring reduction in females, resulting in a prolonged halflife of cortisol and, hence, enhanced central feedback suppression (14). In contrast, CYP3A4 activity is higher in women than in men. However, CYP3A4 is known to eliminate only a small proportion of circulating cortisol $(16,17)$. There is controversy as to whether men and women differ in the activities of 11ß-HSDs $(14,18,19,20)$.

Interaction between gonadal steroids and the metabolism of cortisol has been suggested by several studies $(21,22,23,24)$. However, there is only one cross-sectional study that has investigated glucocorticoid metabolism in children of various ages (18). This study demonstrated that the sex differences in the elimination rate of cortisol, as observed in adulthood, began around the age of
$6 \beta-\mathrm{OH}-$

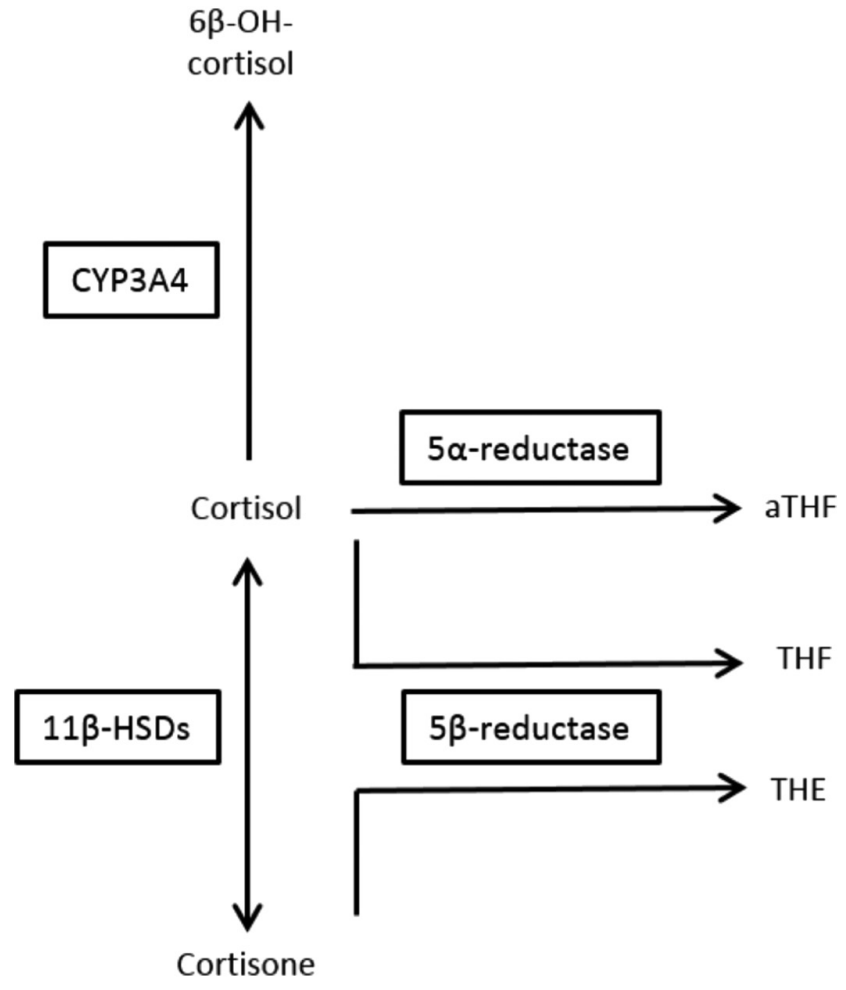

Figure 1

Schematic overview of cortisol metabolism. THF, tetrahydrocortisol; THE, tetrahydrocortisone; aTHF, allotetrahydrocortisol; $6 \beta-\mathrm{OH}$-cortisol, $6 \beta$-hydroxy-cortisol; HSD, hydroxysteroid dehydrogenase; CYP, cytochrome P.

11-12 years and were attributable to a progressive difference in $5 \alpha$-reductase activity (being lower in older girls). Therefore, sexual dimorphism in cortisol metabolism was postulated to emerge during pubertal maturation, suggesting an interplay of adrenal and gonadal axes (18). However, information on pubertal stage was not available in that study (18). To the best of our knowledge, a longitudinal follow-up study of cortisol metabolism from pre- to postpuberty has never been conducted. The aim of this study was to assess the contribution of pubertal development to sexual dimorphism in cortisol production and metabolism.

\section{Materials and methods}

\section{Participants}

We conducted a prospective follow-up study and recruited healthy mono- and dizygotic twin pairs from the Netherlands Twin Register (NTR), a population-based registry $(25,26)$. Twins born between 1995 and 1996 were invited to participate in the BrainScale study of cognition, hormones, and brain development $(27,28)$. BrainScale is a 
collaborative project between the NTR of the VU University Amsterdam and the University Medical Center Utrecht. Four to 8 weeks before the ninth birthday of the twins, a letter of invitation was sent to their parents. Following the invitation letter, the families were contacted by phone to inquire whether they were willing to participate. At the age of 9 years, 109 of the invited twin pairs (51\%) participated in this study. Eighty-two percent of them participated at the age of 12 years, and $80 \%$ participated at the age of 17 years. Seventy-one percent participated at all three occasions. Parents signed informed consent forms for their participating children and for themselves. In addition, twins signed their own informed consent forms at the third occasion (i.e. at the age of 17 years). The current study was approved by the medical ethics committee of the Amsterdam UMC, location VUmc.

Participants were physically examined by a researcher for pubertal stage at ages 9 and 12 years. The examination was based on secondary sexual characteristics according to Marshall and Tanner, that is, breast stage in girls and genital stage in boys $(29,30)$. Prior to the study, researchers were trained in the assessment of pubertal stage. If children felt uncomfortable with physical examination, pubertal stage was determined by self-report based on reference images. Of the participants, 100\% and $80 \%$ were physically examined for pubertal stage at the ages of 9 and 12 years, respectively. At the age of 17 years, pubertal stage was always determined by self-report. In addition, at the age of 17 years, information on the timing of menarche was ascertained. Previous data showed that the inter-rater agreement of self-reported data is relatively low, ranging between 49 and 86\% in girls and between 27 and 78\% in boys, in comparison to researcher-reported data $(31,32$, 33, 34, 35, 36, 37). Therefore, we classified participants as pre-pubertal (Tanner stage 1, hereafter referred to as stage A), early pubertal (Tanner stages 2 and 3, hereafter referred to as stage B), or late-pubertal (Tanner stages 4 and 5 , hereafter referred to as stage $\mathrm{C}$ ). Girls documenting menarche were classified as late-pubertal, regardless of
Tanner stage. For self-reported data, our classification system is expected to have an inter-rater agreement of $82 \%$ in girls and of $75 \%$ in boys, based on Danish reference data (31). These numbers are comparable with the inter-rater reliability of individual Tanner stages between trained assessors (38).

\section{Study protocol}

Participants were examined at the ages of 9, 12, and 17 years. In the week prior to their study visit, subjects collected first voided morning urine samples in tubes provided by us. Participants were requested to store the samples in their refrigerator and to hand them in at the study visit. Samples were stored at $-20^{\circ} \mathrm{C}$ and then at $-80^{\circ} \mathrm{C}$. Samples were thawed only once just before analysis.

\section{Laboratory analysis}

The analysis of cortisol metabolites was conducted at the Edinburgh Clinical Research Facility Mass Spectrometry Core Laboratory. Glucocorticoid metabolites were measured by gas chromatography-tandem mass spectrometry (GC-MS/MS) (39). Samples were analyzed in 15 batches. Creatinine concentrations were measured by the Jaffé method (40). The sum of cortisol metabolites divided by creatinine concentration was used as an index of cortisol production (cortisol metabolite excretion rate). Enzymatic activities were inferred from cortisol metabolite ratios, as depicted in Table 1 . Higher ratios indicate higher

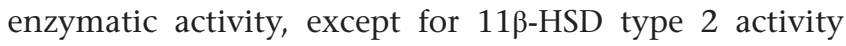
(cortisol/cortisone ratio).

\section{Statistical analysis}

In line with previous analyses in this sample, extreme outliers ( $>3$ s.D. above the phenotypic mean or twin pairs with highly discordant outcomes; on average six and one per index, respectively) were excluded from the statistical

Table 1 Summary of outcomes.

Parameter
(THF + allo-THF + THE $+\alpha$-cortol $+\beta$-cortol $+\alpha$-cortolone $+\beta$-cortolone $) /$ creatinine
allo-THF/F
THF/F
THE/E
F/E
(THF + allo-THF)/THE
$6 \beta-O H$ cortisol/F

\section{Index}

Sum of cortisol metabolites (cortisol metabolite excretion rate)

$5 \alpha$-reductase activity $5 \beta$-reductase activity (a) $5 \beta$-reductase activity (b) $11 \beta$-HSD type 2 activity Balance of $11 \beta$-HSD activities Cytochrome P450 3A4 activity

E, cortisone; F, cortisol; HSD, hydroxysteroid dehydrogenase; THE, tetrahydrocortisone; THF, tetrahydrocortisol.

https://ec.bioscientifica.com https://doi.org/10.1530/EC-20-0123 (c) 2020 The authors Published by Bioscientifica Ltd

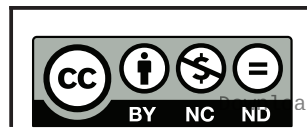

This work is licensed under a Creative Commons Attribution-NonCommercial-NoDerivatives 4.0 internationad ficense ifica . com at 04/26/2023 09:41:02AM 
analysis (41). Next, the data were corrected for batch effects by fitting a random effects model, in which batch was treated as a random effect (42).

\section{Statistical modeling}

Our main aim was to determine the effect of pubertal stage on the outcomes. To this end, we implemented a discrete-time Markov model, in which we estimated the mean and s.D. of each metabolite conditional on the pubertal stage. In this model, each participant was assigned to stage A, B, or C. We took into account that a given participant may transition from stage $\mathrm{A}$ to $\mathrm{B}$ or $\mathrm{C}$ and from stage $\mathrm{B}$ to stage $\mathrm{C}$ between ages 9 and 12 and between 12 and 17 years, respectively. The parameters of the Markov model are the probabilities of being in stage A, B, or C at the age of 9 years, transition probabilities from ages 9 to 12 years, and transition probabilities from ages 12 to 17 years. Because no 9-year olds were assigned to stage $\mathrm{C}$ and no 17-year olds were assigned to stage $\mathrm{A}$, the Markov model includes stages $\mathrm{A}$ and $\mathrm{B}$ at the age of 9 years, stages $\mathrm{A}, \mathrm{B}$, and $\mathrm{C}$ at the age of 12 years, and stages $B$ and $C$ at the age of 17 years. Figure 2 depicts the model. In Fig. $2, \mathrm{p}_{1}$ is the probability of being in stage $A$ at the age of 9 years, $\mathrm{q}_{11}$ and $\mathrm{q}_{12}$ are conditional probabilities governing the transition between ages 9 and 12 years, and $r_{11}$ and $r_{21}$ are conditional probabilities governing the transition between ages 12 and 17 years. For instance, $\mathrm{q}_{12}$ is the probability of transitioning from stage $A$ at the age of 9 years to stage $B$ at the age of 12 years.
As we expected sex differences in probability of the pubertal stages at the age of 9 years and in the transition probabilities from ages 9 to 12 years and from 12 to 17 years, we allowed these parameter to vary with sex (i.e. the probabilities $\mathrm{p}_{1}, \mathrm{q}_{11}, \mathrm{q}_{12}, \mathrm{q}_{22}, \mathrm{r}_{11}$, and $\mathrm{r}_{21}$ varied with sex). In addition, we allowed for sex differences in the means of the metabolites within a given pubertal stage (i.e. the means $\mathrm{m}_{\mathrm{A}}, \mathrm{m}_{\mathrm{B}}$, and $\mathrm{m}_{\mathrm{C}}$ varied with sex). s.D. were constrained to be equal over sexes.

The Markov transition model was implemented in Mplus 6.0 (43). The parameters were estimated by means of maximum likelihood (ML) estimation. For this study, twins were treated as individuals. Therefore, the s.e., CIs, and test statistics were corrected for family clustering. For all outcomes, means were calculated for girls and boys along with their 95\% CIs. Differences between sexes were tested and reported by a two-tailed $P$ value, whereby a $P$ value of $<0.05$ was considered as statically significant. Given the sample size, correction for multiple testing was not conducted. In addition, changes in cortisol parameters were calculated during pubertal development for both sexes.

\section{Results}

A total of 218 participants (50\% females) were included in this study, including 94 monozygotic and 124 dizygotic twins. The monozygotic twin pairs included 23 male and 24 female pairs. The dizygotic twin pairs included 22 male-, 21 female-, and 19 opposite-sex pairs. Participants were tested at $9.1( \pm 0.1), 12.2( \pm 0.3)$, and

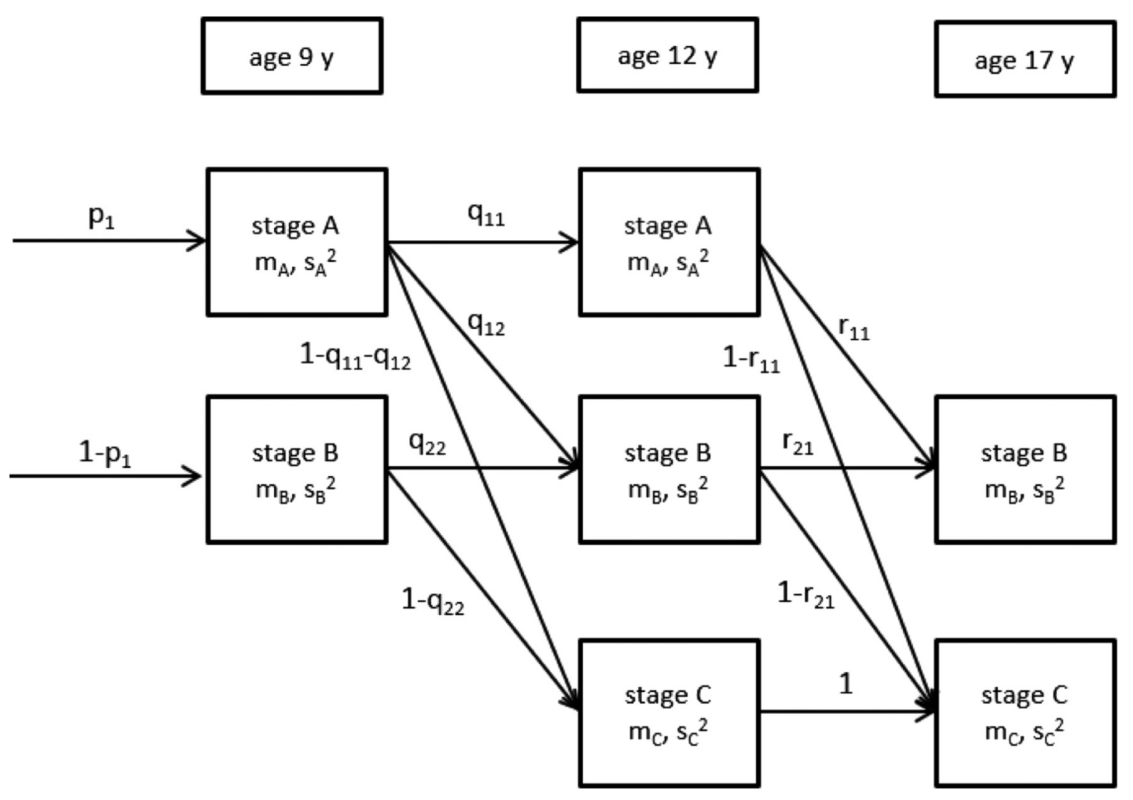

Figure 2

Statistical model: means depending on pubertal stage and sex. *A = pre-pubertal (Tanner stage 1$)$; $B=$ early pubertal (Tanner stage $2-3$ ); $C=$ latepubertal (Tanner stage $4-5)$ ). $p_{1}$ is the probability of being in stage $A$ at the age of 9 years, $q_{11}$ and $\mathrm{q}_{12}$ are conditional probabilities governing the transition between ages 9 and 12 years, and $r_{11}$ and $r_{21}$ are conditional probabilities governing the transition between ages 12 and 17 years. (c) 2020 The authors Published by Bioscientifica Ltd
This work is licensed under a Creative Commons Attribution-NonCommercial-NoDerivatives 4.0 Internationab ficense.ifica.com at 04/26/2023 09:41:02AM 
Table 2 Characteristics of participants.

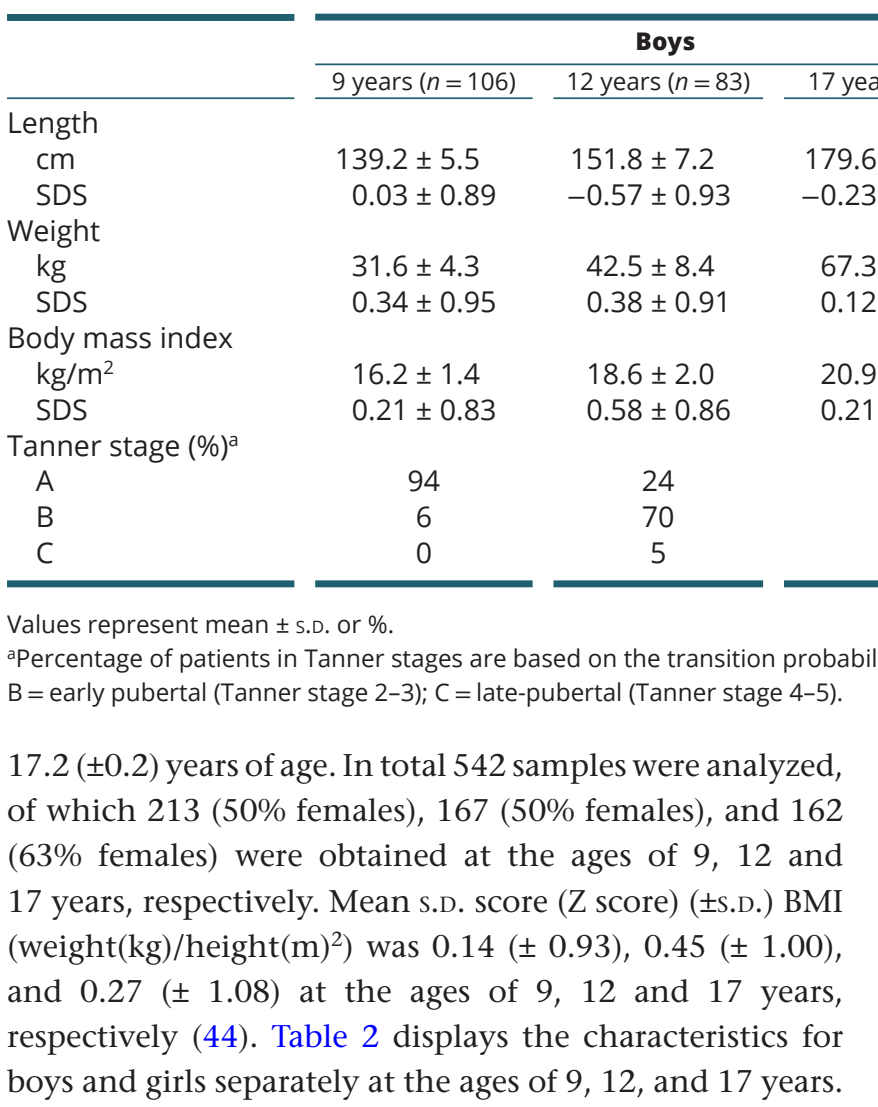

\section{Pubertal development}

The Markov model parameter estimates are shown in Table 3. At the age of 9 years, as expected, boys were more likely to be pre-pubertal than girls (0.944 vs 0.811). At the age of 12 years, the entire spectrum of pubertal stages were observed in both sexes, although in girls puberty was generally more advanced. At the age of 17 years, all girls were classified as late-pubertal, while, contrary to expectation, still $20 \%$ of the boys were early pubertal.

Consequently, sex differences in the transition probabilities from 9 to 12 years and from 12 to 17 years were also observed. For instance, the probability of remaining in stage A between the ages of 9 and 12 years was markedly higher in boys $(0.259)$ than in girls $(0.127)$. The probability of moving from stage A to $\mathrm{C}$ between 9 and 12 years was higher in girls than in boys ( 0.282 vs 0.025$)$.

\section{Sexual dimorphism in cortisol production and metabolism during pubertal development}

Table 4 displays the sex-specific means for cortisol metabolite excretion rate and cortisol metabolite ratios by pubertal stage. Cortisol metabolite excretion rate did not statistically differ between sexes at any stage. The cortisol metabolite ratios were similar between sexes at stage $\mathrm{A}$, but diverged during pubertal development. In boys at stages $\mathrm{B}$ and $\mathrm{C}$, as compared to girls of the same stage, the balance of $11 \beta$-HSD activities ((THF + allo-THF)/THE ratio) favored cortisol. At stage B, this difference could be partially attributable to a lower 11ß-HSD type 2 activity (cortisol/cortisone ratio) in boys. Girls at stage $\mathrm{C}$, as compared to boys of the same stage, had lower activities of $5 \alpha-$ (allo-THF/F ratio) and $5 \beta$-reductases (THE/E ratio). There were no differences in CYP3A4 activity (6-OH cortisol/cortisol ratio) between sexes at stages B or C.

Table 3 Pubertal development and transition probabilities according our Markov model.

\begin{tabular}{|c|c|c|c|c|}
\hline Age (years) & $\begin{array}{l}\text { Pubertal } \\
\text { development }\end{array}$ & $\begin{array}{l}\text { Markov } \\
\text { parameters }\end{array}$ & Girls & Boys \\
\hline \multirow[t]{2}{*}{9} & A & $\mathrm{p}_{1}$ & 0.811 & 0.944 \\
\hline & B & $1-p_{1}$ & 0.189 & 0.056 \\
\hline \multirow[t]{5}{*}{$9->12$} & $A->A$ & $q_{11}$ & 0.127 & 0.259 \\
\hline & $A->B$ & $\mathrm{q}_{12}$ & 0.592 & 0.717 \\
\hline & $A->C$ & $1-q_{11}-q_{12}$ & 0.282 & 0.025 \\
\hline & $B->B$ & $\mathrm{q}_{22}$ & 0.733 & 0.500 \\
\hline & $B->C$ & $1-q_{22}$ & 0.267 & 0.500 \\
\hline \multirow[t]{5}{*}{$12->17$} & $A->B$ & $r_{11}$ & 0.000 & 0.491 \\
\hline & $A->C$ & $1-r_{11}$ & 1.000 & 0.509 \\
\hline & $B->B$ & $r_{21}$ & 0.000 & 0.110 \\
\hline & $B->C$ & $1-r_{21}$ & 1.000 & 0.890 \\
\hline & $C->C$ & 1 & 1.000 & 1.000 \\
\hline
\end{tabular}

${ }^{\mathrm{a}} \mathrm{A}=$ pre-pubertal (Tanner stage 1$), \mathrm{B}=$ early pubertal (Tanner stage $2-3$ ), $\mathrm{C}=$ late-pubertal (Tanner stage 4-5). 
Table 4 Cortisol metabolite excretion rate and cortisol metabolite ratios by pubertal stage.

\begin{tabular}{|c|c|}
\hline Parameter & $\begin{array}{l}\text { Pubertal } \\
\text { stage }^{a}\end{array}$ \\
\hline $\begin{array}{l}\text { Cortisol metabolite } \\
\text { excretion rate }\end{array}$ & $\begin{array}{l}A \\
B \\
C\end{array}$ \\
\hline $\begin{array}{l}5 \alpha \text {-reductase activity } \\
(\text { allo-THF/F) }\end{array}$ & $\begin{array}{l}\text { A } \\
B \\
C\end{array}$ \\
\hline $\begin{array}{l}5 \beta \text {-reductase activity } \\
\text { (a) }(T H F / F)\end{array}$ & $\begin{array}{l}A \\
B \\
C\end{array}$ \\
\hline $\begin{array}{l}5 \beta \text {-reductase activity } \\
\text { (b) (THF/E) }\end{array}$ & $\begin{array}{l}\text { A } \\
B \\
C\end{array}$ \\
\hline $\begin{array}{l}11 \beta \text {-HSD type } 2 \\
\text { activity }(F / E)\end{array}$ & $\begin{array}{l}\text { A } \\
B \\
C\end{array}$ \\
\hline $\begin{array}{l}\text { Balance of } 11 \beta-H S D \\
\text { activities } \\
((T H F+\text { allo-THF)/THE) }\end{array}$ & $\begin{array}{l}\text { A } \\
B \\
C\end{array}$ \\
\hline $\begin{array}{l}\text { Cytochrome P450 } \\
\text { 3A4 activity } \\
(6 \beta-O H \text { cortisol/F) }\end{array}$ & $\begin{array}{l}A \\
B \\
C\end{array}$ \\
\hline
\end{tabular}

\begin{tabular}{c}
\hline Mean girls $(95 \% \mathrm{Cl})$ \\
\hline $0.581(0.533-0.629)$ \\
$0.577(0.522-0.631)$ \\
$0.448(0.407-0.489)$ \\
$8.982(8.087-9.876)$ \\
$9.909(8.832-10.987)$ \\
$5.504(4.724-6.284)$ \\
$9.164(8.388-9.939)$ \\
$11.116(10.413-11.820)$ \\
$9.792(9.096-10.487)$ \\
$27.101(25.358-28.845)$ \\
$31.517(28.929-34.106)$ \\
$26.096(24.404-27.787)$ \\
$0.896(0.846-0.946)$ \\
$0.772(0.688-0.855)$ \\
$1.264(1.168-1.359)$ \\
$0.613(0.572-0.655)$ \\
$0.552(0.497-0.607)$ \\
$0.669(0.631-0.708)$ \\
$1.893(1.748-2.038)$ \\
$1.907(1.712-2.101)$ \\
$1.773(1.606-1.940)$
\end{tabular}

\begin{tabular}{c}
\hline Mean boys $(95 \% \mathrm{Cl})$ \\
\hline $0.571(0.511-0.631)$ \\
$0.512(0.446-0.579)$ \\
$0.487(0.411-0.563)$ \\
$9.405(8.158-10.653)$ \\
$8.255(6.784-9.726)$ \\
$8.558(7.135-9.981)$ \\
$10.195(9.014-11.377)$ \\
$11.367(9.809-13.223)$ \\
$10.729(9.453-12.006)$ \\
$27.409(25.140-29.678)$ \\
$29.465(25.960-32.969)$ \\
$30.468(26.861-34.076)$ \\
$0.872(0.799-0.945)$ \\
$0.915(0.809-1.022)$ \\
$1.242(1.102-1.382)$ \\
$0.623(0.572-0.675)$ \\
$0.640(0.570-0.711)$ \\
$0.793(0.716-0.871)$ \\
$1.955(1.734-2.176)$ \\
$1.834(1.560-2.109)$ \\
$1.859(1.598-2.120)$ \\
\hline
\end{tabular}

$\begin{array}{r}\hline \text { Variances } \\ \hline 0.047 \\ 0.047 \\ 0.056 \\ 24.048 \\ 21.623 \\ 19.815 \\ 20.976 \\ 29.161 \\ 15.494 \\ 70.990 \\ 132.215 \\ 123.162 \\ 0.100 \\ 0.106 \\ 0.217 \\ 0.035 \\ 0.054 \\ 0.056 \\ 0.630 \\ 0.910 \\ 0.604 \\ \hline\end{array}$

\begin{tabular}{c}
\hline Sex difference \\
\hline$P$ value \\
\hline 0.777 \\
0.108 \\
0.400 \\
0.576 \\
0.064 \\
$<\mathbf{0 . 0 0 1}$ \\
0.151 \\
0.791 \\
0.227 \\
0.823 \\
0.335 \\
$\mathbf{0 . 0 4 6}$ \\
0.593 \\
$\mathbf{0 . 0 2 7}$ \\
0.796 \\
0.741 \\
$\mathbf{0 . 0 4 0}$ \\
$\mathbf{0 . 0 0 8}$ \\
0.645 \\
0.663 \\
0.590 \\
\hline
\end{tabular}

\begin{tabular}{c}
\hline Effect size \\
\hline Cohen's D \\
\hline 0.046 \\
0.300 \\
0.165 \\
0.086 \\
0.356 \\
0.686 \\
0.225 \\
0.046 \\
0.238 \\
0.037 \\
0.178 \\
0.394 \\
0.076 \\
0.439 \\
0.047 \\
0.053 \\
0.379 \\
0.524 \\
0.078 \\
0.077 \\
0.111 \\
\hline
\end{tabular}

${ }^{\mathrm{a}} \mathrm{A}=$ pre-pubertal (Tanner stage 1); $\mathrm{B}=$ early pubertal (Tanner stage 2-3); $\mathrm{C}=$ late-pubertal (Tanner stage 4-5).

Table 5 presents the changes in cortisol metabolite excretion rate and cortisol metabolite ratios during pubertal development by sex. In both sexes cortisol metabolite excretion rate decreased with pubertal progression, albeit with few differences. In boys, cortisol metabolite excretion rate decreased between stages A and $\mathrm{B}$, while in girls it decreased considerably between stages B and C. In both sexes between stages B and C the balance of 11 $\beta$-HSD activities ((THF + allo-THF)/THE) changed in the direction of cortisol, which could partially be explained by decreased $11 \beta$-HSD type 2 activity (cortisol/cortisone ratio). In girls, the activities of A-ring reductases (ratios of allo-THF/F, THF/F, and THE/E) increased (with the exception of $5 \alpha$-reductase activity) between stages $\mathrm{A}$ and $\mathrm{B}$ and decreased between stages B and C. In boys, these parameters did not change during pubertal development. In both sexes, CYP3A4 activity (6-OH cortisol/cortisol ratio) was stable across pubertal development.

\section{Discussion}

In this longitudinal study, we have demonstrated that the excretion of cortisol metabolites diverges between sexes with advancing pubertal maturation. Therefore, our study suggests that the sexual dimorphism in cortisol metabolism that generally starts around the age of 11 is a hormonally driven process, either directly, by influencing gene expression, or indirectly, by impacting on body composition.

Previous studies showed that adult men and women differ in the excretion rate of cortisol metabolites, which was higher in males $(13,45)$. Wudy et al. found that these differences emerged from the age of 11 to 12 years (18), suggestive of an important role of gonadal hormones. However, their study lacked an assessment of pubertal status. In our study, which included repeated assessment of Tanner pubertal stage, we found that the excretion rate of cortisol metabolites decreased significantly in girls between early and late-pubertal stage, suggestive of an effect of pubertal development on the excretion rate of cortisol metabolites in girls. In contrast to previous research (18), we were not able to detect statistically significant differences in cortisol metabolite excretion rate between sexes which might be due to the use of morning instead of 24-h urine or the relatively small sample size.

Our data provided evidence for a sexual dimorphism in cortisol metabolism, as assessed by ratios reflecting the activities of the enzymes involved. We found that with advancing pubertal maturation in females, as compared to males, the balance of $11 \beta$-HSDs progressively favored cortisone and that the proportion of A-ring reduced metabolites was lower, in line with data in adults (13, $14,15,20,45)$. During pubertal maturation, levels of sex steroids increase gradually along with the development

This work is licensed under a Creative Commons Attribution-NonCommercial-NoDerivatives 4.0 International dicense.ifica com at 04/26/2023 09:41:02AM 
Table 5 Changes in cortisol metabolite excretion rate and cortisol metabolite ratios during pubertal development.

\begin{tabular}{|c|c|}
\hline Parameter & Pubertal stage $^{a}$ \\
\hline $\begin{array}{l}\text { Cortisol metabolite } \\
\text { excretion rate }\end{array}$ & $\begin{array}{l}A->B \\
B \rightarrow C\end{array}$ \\
\hline $5 \alpha$-reductase activity & $\begin{array}{l}A \rightarrow B \\
B \rightarrow C\end{array}$ \\
\hline $5 \beta$-reductase activity (a) & $\begin{array}{l}A->B \\
B->C\end{array}$ \\
\hline $5 \beta$-reductase activity (b) & $\begin{array}{l}A \rightarrow B \\
B \rightarrow C\end{array}$ \\
\hline $11 \beta$-HSD type 2 activity & $\begin{array}{l}A->B \\
B->C\end{array}$ \\
\hline $\begin{array}{l}\text { Balance of } 11 \beta-\text { HSD } \\
\text { activities }\end{array}$ & $\begin{array}{l}A \rightarrow B \\
B \rightarrow C\end{array}$ \\
\hline $\begin{array}{l}\text { Cytochrome P450 3A4 } \\
\text { activity }\end{array}$ & $\begin{array}{l}A \rightarrow B \\
B \rightarrow C\end{array}$ \\
\hline
\end{tabular}

\begin{tabular}{c}
\hline Girls Mean difference $(95 \% \mathrm{Cl})$ \\
\hline$-0.004(-0.069-0.060)$ \\
$-0.128(-0.188-0.068)$ \\
$0.928(-0.234-2.090)$ \\
$-4.406(-5.703--3.109)$ \\
$1.953(1.097-2.808)$ \\
$-1.325(-2.366--0.284)$ \\
$4.416(1.501-7.331)$ \\
$-5.422(-8.335--2.508)$ \\
$-0.124(-0.213--0.036)$ \\
$0.492(0.363-0.620)$ \\
$-0.061(-0.119--0.004)$ \\
$0.117(0.046-0.188)$ \\
$0.013(-0.205-0.232)$ \\
$-0.134(-0.400-0.133)$ \\
\hline
\end{tabular}

$\begin{array}{r}\hline \text { P value } \\ \hline 0.913 \\ <\mathbf{0 . 0 0 1} \\ 0.189 \\ <\mathbf{0 . 0 0 1} \\ <\mathbf{0 . 0 0 1} \\ \mathbf{0 . 0 3 6} \\ \mathbf{0 . 0 1 3} \\ \mathbf{0 . 0 0 2} \\ \mathbf{0 . 0 2 1} \\ <\mathbf{0 . 0 0 1} \\ 0.079 \\ \mathbf{0 . 0 0 7} \\ 0.919 \\ 0.410 \\ \hline\end{array}$

\begin{tabular}{c}
\hline Boys Mean difference $(95 \% \mathrm{Cl})$ \\
\hline$-0.059(-0.160--0.012)$ \\
$-0.024(-0.097-0.048)$ \\
$-1.150(-2.367--1.150)$ \\
$0.303(-0.945--0.303)$ \\
$1.172(-0.209-2.553)$ \\
$-0.638(-2.113-0.837)$ \\
$2.056(-0.359-4.471)$ \\
$1.003(-2.180-4.186)$ \\
$0.043(-0.025-0.111)$ \\
$0.326(0.220-0.433)$ \\
$0.016(-0.031-0.063)$ \\
$0.153(0.089-0.218)$ \\
$-0.121(-0.315-0.073)$ \\
$0.025(-0.251-0.301)$ \\
\hline
\end{tabular}

$\begin{array}{r}\hline \boldsymbol{P} \text { value } \\ \hline \mathbf{0 . 0 4 0} \\ 0.580 \\ 0.120 \\ 0.690 \\ 0.163 \\ 0.477 \\ 0.161 \\ 0.604 \\ 0.302 \\ <\mathbf{0 . 0 0 1} \\ 0.566 \\ <\mathbf{0 . 0 0 1} \\ 0.304 \\ 0.883 \\ \hline\end{array}$

${ }^{\mathrm{a}} \mathrm{A}=$ pre-pubertal (Tanner stage 1); $\mathrm{B}=$ early pubertal (Tanner stage $2-3$ ); $\mathrm{C}=$ late-pubertal (Tanner stage 4-5).

of secondary sexual characteristics (46). Therefore, our findings suggest that sex steroids influence cortisol metabolism either directly, for example, by influencing gene expression, or indirectly, by impacting on body composition $(47,48,49)$.

With advancing pubertal development, differences in body composition emerge between sexes; girls gain more mass and boys acquire more fat-free mass and skeletal mass (50). These differences are regulated by endocrine factors, including gonadal steroids and growth hormone (51), in addition to genetic and environmental factors. Body composition is strongly associated with HPA-axis activity, both in adulthood and childhood $(52,53)$, and the observed differences between sexes in cortisol parameters that emerge during pubertal development could (partially) be explained by progressive differences in body composition. Although males and females did not differ in BMI at any age, unfortunately our study lacked a more detailed assessment of body composition.

It is unclear whether the sex differences in cortisol metabolism that we observed are androgen- or estrogen mediated. A study in adult men showed that testosterone reduced the $\mathrm{CRH}$-stimulated rise in serum cortisol, in spite of increased ACTH, suggestive of adrenal hyporesponsiveness (54). Evidence for an effect of androgens on glucocorticoid metabolism was provided by other studies $(55,56$, 57). It has been demonstrated by multiple studies that women with polycystic ovary syndrome - a condition characterized by increased androgen production - had a higher $5 \alpha$-reductase activity than BMI-matched controls (55). However, this may be part of the PCOS trait rather than an effect of hyperandrogenism, as their daughters already had a greater $5 \alpha$-reductase activity, in spite of a similar androgen metabolite excretion rate, from early childhood than age-matched controls (56). In contrast, experiments in gonadectomized male rats suggested that androgens suppress the expression and/or the activity of hepatic A-ring reductases (57). In addition, the same experiments suggested that androgens increase 11 $\beta$-HSD type 1 in liver and adipose tissue (57).

Studies in rats and humans suggest that estrogens could also influence glucocorticoid metabolism, though findings were contradictory. Several studies in rodents have shown that the expression and/or the activity of A-ring reductases and 11ß-HSD type 1 was upregulated and downregulated by estrogen, respectively $(19,22,58$, $59,60,61)$. In contrast, in humans the activity of these enzymes was independent of the phase of the menstrual cycle or, after menopause, use of estrogen replacement therapy $(14,15,20)$.

Our study has several strengths and limitations. The major strength of our study was the long follow-up period of 8 years, enabling us to assess the contribution of pubertal maturation to sexual dimorphism in HPAaxis functioning. Moreover, participants were recruited from a population-based twin register and the numbers remaining into follow-up were relatively high for an age group that is notoriously difficult to engage in longitudinal studies. Another strength is that all measurements were performed in the same laboratory at the same time. Samples were frozen as soon as possible and were thawed only once prior to analysis, which enhances stability (62).

Our study also has its limitations. First, the Brain Scale study was not powered specifically for the present study and, hence, a sample size calculation was not performed prior to analysis, which might explain our inability to detect differences in cortisol metabolite excretion rate between sexes. Second, some limitations related to our 
outcome should be acknowledged. Enzymatic activities were estimated by ratios of metabolites in morning urine, which estimate activity only globally. Since cortisol is secreted in a circadian rhythm, a 24-h-urine sample would have been preferred. In addition, both short- and long-term stability of cortisol production and metabolism are low, which could have influenced our results (63, 64). Third, a residual age effect could not be excluded. In order to distinguish between a residual age effect and the effect of pubertal maturation, a larger sample size is warranted. Fourth, Tanner pubertal stages were, for an important part, assessed by self-report, which might result in misclassification, notably under classification (31). Nevertheless, our approach (i.e. classifying according to pre-, early, and late-pubertal stages and the use of the Markov model) is likely to reduce misclassification.

\section{Conclusion}

With advancing pubertal maturation, sexual dimorphism in cortisol metabolism became increasingly manifest, while no differences were seen prepubertally. These differences could emerge from direct or indirect effects of sex steroids on cortisol metabolism.

\section{Declaration of interest}

The authors declare that there is no conflict of interest that could be perceived as prejudicing the impartiality of the research reported.

\section{Funding}

R A and B R W were supported by a British Heart Foundation Programme Grant and by a Wellcome Trust equipment grant. This work was supported by the Netherlands Organization for Scientific Research (NWO, 51.02.060, 668.772; NWO-MagW 480-04-004; NWO/SPI 56-464-14192). DIB acknowledges KNAW Academy Professor Award (PAH/6635).

\section{Acknowledgements}

The authors thank the twins and their parents for making this study possible. The authors thank the staff of the Edinburgh Mass Spectrometry Core for specialist support. B R W is a Wellcome Trust Investigator.

\section{References}

1 Fairweather D, Petri MA, Coronado MJ \& Cooper LT. Autoimmune heart disease: role of sex hormones and autoantibodies in disease pathogenesis. Expert Review of Clinical Immunology 20128 269-284. (https://doi.org/10.1586/eci.12.10)

2 World Health Organization. Gender and Women's Mental Health. Gender Disparities and Mental Health: The Facts. Geneva, Switzerland: WHO. (available at: https://www.who.int/mental_health/prevention/ genderwomen/en/)
3 Schacht R, Rauch KL \& Borgerhoff Mulder M. Too many men: the violence problem? Trends in Ecology and Evolution 201429 214-222. (https://doi.org/10.1016/j.tree.2014.02.001)

4 Appelman Y, van Rijn BB, Ten Haaf ME, Boersma E \& Peters SA. Sex differences in cardiovascular risk factors and disease prevention. Atherosclerosis 2015241 211-218. (https://doi.org/10.1016/j. atherosclerosis.2015.01.027)

5 Silverman MN \& Sternberg EM. Glucocorticoid regulation of inflammation and its functional correlates: from HPA axis to glucocorticoid receptor dysfunction. Annals of the New York Academy of Sciences 20121261 55-63. (https://doi.org/10.1111/j.17496632.2012.06633.x)

6 Malhi GS \& Mann JJ. Depression. Lancet 2018392 2299-2312. (https://doi.org/10.1016/S0140-6736(18)31948-2)

7 Liyanarachchi K, Ross R \& Debono M. Human studies on hypothalamo-pituitary-adrenal (HPA) axis. Best Practice and Research: Clinical Endocrinology and Metabolism 201731 459-473. (https://doi. org/10.1016/j.beem.2017.10.011)

8 Dekker MJ, Koper JW, van Aken MO, Pols HA, Hofman A, de Jong FH, Kirschbaum C, Witteman JC, Lamberts SW \& Tiemeier H. Salivary cortisol is related to atherosclerosis of carotid arteries. Journal of Clinical Endocrinology and Metabolism 200893 3741-3747. (https:// doi.org/10.1210/jc.2008-0496)

9 Zorn JV, Schur RR, Boks MP, Kahn RS, Joels M \& Vinkers CH. Cortisol stress reactivity across psychiatric disorders: a systematic review and meta-analysis. Psychoneuroendocrinology 201777 25-36. (https://doi. org/10.1016/j.psyneuen.2016.11.036)

10 World Health Organization. Biological Mechanisms Related to Cardiovascular and Metabolic Effects by Environmental Noise. Geneva, Switzerland: WHO, 2018. (available at: http://www.euro.who.int/ en/health-topics/environment-and-health/noise/publications/2018/ biological-mechanisms-related-to-cardiovascular-and-metaboliceffects-by-environmental-noise)

11 van der Voorn B, Hollanders JJ, Ket JCF, Rotteveel J \& Finken MJJ. Gender-specific differences in hypothalamus-pituitary-adrenal axis activity during childhood: a systematic review and meta-analysis. Biology of Sex Differences 20178 3. (https://doi.org/10.1186/s13293016-0123-5)

12 Methlie P, Husebye EE, Hustad S, Lien EA \& Lovas K. Grapefruit juice and licorice increase cortisol availability in patients with Addison's disease. European Journal of Endocrinology 2011165 761-769. (https:// doi.org/10.1530/EJE-11-0518)

13 Shamim W, Yousufuddin M, Bakhai A, Coats AJ \& Honour JW. Gender differences in the urinary excretion rates of cortisol and androgen metabolites. Annals of Clinical Biochemistry 200037 770-774. (https://doi.org/10.1258/0004563001900084)

14 Finken MJ, Andrews RC, Andrew R \& Walker BR. Cortisol metabolism in healthy young adults: sexual dimorphism in activities of A-ring reductases, but not 11 beta-hydroxysteroid dehydrogenases. Journal of Clinical Endocrinology and Metabolism 199984 3316-3321. (https:// doi.org/10.1210/jcem.84.9.6009)

15 Andrew R, Phillips DI \& Walker BR. Obesity and gender influence cortisol secretion and metabolism in man. Journal of Clinical Endocrinology and Metabolism 199883 1806-1809. (https://doi. org/10.1210/jcem.83.5.4951)

16 Lutz U, Bittner N, Ufer M \& Lutz WK. Quantification of cortisol and 6 beta-hydroxycortisol in human urine by LC-MS/MS, and gender-specific evaluation of the metabolic ratio as biomarker of CYP3A activity. Journal of Chromatography: B, Analytical Technologies in the Biomedical and Life Sciences 2010878 97-101. (https://doi. org/10.1016/j.jchromb.2009.11.023)

17 Inagaki K, Inagaki M, Kataoka T, Sekido I, Gill MA \& Nishida M. A wide interindividual variability of urinary 6beta-hydroxycortisol to free cortisol in 487 healthy Japanese subjects in near basal condition. Therapeutic Drug Monitoring 200224 722-727. (https://doi. org/10.1097/00007691-200212000-00007) 
18 Wudy SA, Hartmann MF \& Remer T. Sexual dimorphism in cortisol secretion starts after age 10 in healthy children: urinary cortisol metabolite excretion rates during growth. American Journal of Physiology: Endocrinology and Metabolism 2007293 E970-E976. (https://doi.org/10.1152/ajpendo.00495.2006)

19 Low SC, Chapman KE, Edwards CR, Wells T, Robinson IC \& Seckl JR. Sexual dimorphism of hepatic 11 beta-hydroxysteroid dehydrogenase in the rat: the role of growth hormone patterns. Journal of Endocrinology 1994143 541-548. (https://doi.org/10.1677/ joe.0.1430541)

20 Toogood AA, Taylor NF, Shalet SM \& Monson JP. Sexual dimorphism of cortisol metabolism is maintained in elderly subjects and is not oestrogen dependent. Clinical Endocrinology 200052 61-66. (https:// doi.org/10.1046/j.1365-2265.2000.00874.x)

21 Yokoi H, Tsuruo Y, Miyamoto T \& Ishimura K. Steroid 5 alphareductase type 1 immunolocalized in the adrenal gland of normal, gonadectomized, and sex hormone-supplemented rats. Histochemistry and Cell Biology 1998109 127-134. (https://doi.org/10.1007/ s004180050210)

22 Jamieson PM, Nyirenda MJ, Walker BR, Chapman KE \& Seckl JR. Interactions between oestradiol and glucocorticoid regulatory effects on liver-specific glucocorticoid-inducible genes: possible evidence for a role of hepatic 11beta-hydroxysteroid dehydrogenase type 1 . Journal of Endocrinology 1999160 103-109. (https://doi.org/10.1677/ joe.0.1600103)

23 Nowak KW, Neri G, Nussdorfer GG \& Malendowicz LK. Effects of sex hormones on the steroidogenic activity of dispersed adrenocortical cells of the rat adrenal cortex. Life Sciences $1995 \mathbf{5 7} 833-837$. (https:// doi.org/10.1016/0024-3205(95)02015-b)

24 Oyola MG \& Handa RJ. Hypothalamic-pituitary-adrenal and hypothalamic-pituitary-gonadal axes: sex differences in regulation of stress responsivity. Stress 201720 476-494. (https://doi.org/10.1080/ 10253890.2017.1369523)

25 Boomsma DI, de Geus EJ, Vink JM, Stubbe JH, Distel MA, Hottenga JJ, Posthuma D, van Beijsterveldt TC, Hudziak JJ, Bartels M, et al. Netherlands Twin Register: from twins to twin families. Twin Research and Human Genetics 20069 849-857. (https://doi. org/10.1375/183242706779462426)

26 Boomsma DI, Vink JM, van Beijsterveldt TC, de Geus EJ, Beem AL, Mulder EJ, Derks EM, Riese H, Willemsen GA, Bartels M, et al. Netherlands Twin Register: a focus on longitudinal research. Twin Research 20025 401-406. (https://doi. org/10.1375/136905202320906174)

27 van Soelen IL, Brouwer RM, Peper JS, van Leeuwen M, Koenis MM, van Beijsterveldt TC, Swagerman SC, Kahn RS, Hulshoff Pol HE \& Boomsma DI. Brain SCALE: brain structure and cognition: an adolescent longitudinal twin study into the genetic etiology of individual differences. Twin Research and Human Genetics 201215 453-467. (https://doi.org/10.1017/thg.2012.4)

28 Teeuw J, Brouwer RM, Koenis MMG, Swagerman SC, Boomsma DI $\&$ Hulshoff Pol HE. Genetic influences on the development of cerebral cortical thickness during childhood and adolescence in a Dutch longitudinal twin sample: the Brainscale study. Cerebral Cortex 201929 978-993. (https://doi.org/10.1093/cercor/bhy005)

29 Marshall WA \& Tanner JM. Variations in the pattern of pubertal changes in boys. Archives of Disease in Childhood 197045 13-23. (https://doi.org/10.1136/adc.45.239.13)

30 Marshall WA \& Tanner JM. Variations in pattern of pubertal changes in girls. Archives of Disease in Childhood 196944 291-303. (https:// doi.org/10.1136/adc.44.235.291)

31 Ernst A, Lauridsen LLB, Brix N, Kjersgaard C, Olsen J, Parner ET, Clausen N, Olsen LH \& Ramlau-Hansen CH. Self-assessment of pubertal development in a puberty cohort. Journal of Pediatric Endocrinology and Metabolism 201831 763-772. (https://doi. org/10.1515/jpem-2018-0178)
32 Wu Y, Schreiber GB, Klementowicz V, Biro F \& Wright D. Racial differences in accuracy of self-assessment of sexual maturation among young black and white girls. Journal of Adolescent Health 200128 197-203. (https://doi.org/10.1016/s1054-139x(00)00163-4)

33 Desmangles JC, Lappe JM, Lipaczewski G \& Haynatzki G. Accuracy of pubertal Tanner staging self-reporting. Journal of Pediatric Endocrinology and Metabolism 200619 213-221. (https://doi. org/10.1515/jpem.2006.19.3.213)

34 Hergenroeder AC, Hill RB, Wong WW, Sangi-Haghpeykar H \& Taylor W. Validity of self-assessment of pubertal maturation in African American and European American adolescents. Journal of Adolescent Health 1999 24 201-205. (https://doi.org/10.1016/s1054-139x(98)00110-4)

35 Schlossberger NM, Turner RA \& Irwin Jr CE. Validity of selfreport of pubertal maturation in early adolescents. Journal of Adolescent Health 199213 109-113. (https://doi.org/10.1016/1054139x(92)90075-m)

36 Bonat S, Pathomvanich A, Keil MF, Field AE \& Yanovski JA. Selfassessment of pubertal stage in overweight children. Pediatrics 2002 110 743-747. (https://doi.org/10.1542/peds.110.4.743)

37 Sun Y, Tao FB, Su PY \& China Puberty Research Collaboration. Self-assessment of pubertal Tanner stage by realistic colour images in representative Chinese obese and non-obese children and adolescents. Acta Paediatrica 2012101 e163-e166. (https://doi. org/10.1111/j.1651-2227.2011.02568.x)

38 Slora EJ, Bocian AB, Herman-Giddens ME, Harris DL, Pedlow SE, Dowshen SA \& Wasserman RC. Assessing inter-rater reliability (IRR) of Tanner staging and orchidometer use with boys: a study from PROS. Journal of Pediatric Endocrinology and Metabolism 200922 291-299. (https://doi.org/10.1515/jpem.2009.22.4.291)

39 Homer N, Kothiya S, Rutter A, Walker BR \& Andrew R. Gas chromatography tandem mass spectrometry offers advantages for urinary steroids analysis. Analytical Biochemistry 2017538 34-37. (https://doi.org/10.1016/j.ab.2017.09.002)

40 Apple F, Bandt C, Prosch A, Erlandson G, Holmstrom V, Scholen J \& Googins M. Creatinine clearance: enzymatic vs Jaffe determinations of creatinine in plasma and urine. Clinical Chemistry 198632 388-390. (https://doi.org/10.1093/clinchem/32.2.388)

41 van Keulen BJ, Dolan CV, Andrew R, Walker BR, Hulshoff Pol HE, Boomsma DI, Rotteveel J \& Finken MJJ. Heritability of cortisol production and metabolism throughout adolescence. Journal of Clinical Endocrinology and Metabolism 2020 105. (https://doi. org/10.1210/clinem/dgz016)

42 Odintsova VV, Willemsen G, Dolan CV, Hottenga JJ, Martin NG, Slagboom PE, Ordonana JR \& Boomsma DI. Establishing a twin register: an invaluable resource for (behavior) genetic, epidemiological, biomarker, and 'omics' studies. Twin Research and Human Genetics 201821 239-252. (https://doi.org/10.1017/ thg.2018.23)

43 Muthén LK \& Muthén BO. Mplus User's Guide, 6th ed. Los Angeles, CA, USA: Muthén \& Muthén, 2007. (available at: https://www. statmodel.com/download/usersguide/Mplus\%20Users\%20 Guide\%20v6.pdf)

44 TNO. Vijfde Landelijke Groeistudie. The Hague, Netherlands: TNO, 2010. (available at: https://www.tno.nl/nl/aandachtsgebieden/ gezond-leven/roadmaps/youth/landelijke-groeistudie-toont-toenameovergewicht-kinderen/)

45 Raven PW \& Taylor NF. Sex differences in the human metabolism of cortisol. Endocrine Research 199622 751-755. (https://doi. org/10.1080/07435809609043772)

46 Varlinskaya EI, Vetter-O'Hagen CS \& Spear LP. Puberty and gonadal hormones: role in adolescent-typical behavioral alterations. Hormones and Behavior 201364 343-349. (https://doi.org/10.1016/j. yhbeh.2012.11.012)

47 Johnstone AM, Faber P, Andrew R, Gibney ER, Elia M, Lobley G, Stubbs RJ \& Walker BR. Influence of short-term dietary weight https://ec.bioscientifica.com

https://doi.org/10.1530/EC-20-0123
(C) 2020 The authors Published by Bioscientifica Ltd
This work is licensed under a Creative Commons Attribution-NonCommercial-NoDerivatives 4.0 Internationab ficense.ifica . com at 04/26/2023 09:41:02AM 
loss on cortisol secretion and metabolism in obese men. European Journal of Endocrinology 2004150 185-194. (https://doi.org/10.1530/ eje.0.1500185)

48 Walker BR \& Andrew R. Tissue production of cortisol by 11 betahydroxysteroid dehydrogenase type 1 and metabolic disease. Annals of the New York Academy of Sciences 20061083 165-184. (https://doi. org/10.1196/annals.1367.012)

49 Bredella MA. Sex differences in body composition. Advances in Experimental Medicine and Biology 20171043 9-27. (https://doi. org/10.1007/978-3-319-70178-3_2)

50 Veldhuis JD, Roemmich JN, Richmond EJ, Rogol AD, Lovejoy JC, Sheffield-Moore M, Mauras N \& Bowers CY. Endocrine control of body composition in infancy, childhood, and puberty. Endocrine Reviews 200526 114-146. (https://doi.org/10.1210/er.2003-0038)

51 Loomba-Albrecht LA \& Styne DM. Effect of puberty on body composition. Current Opinion in Endocrinology, Diabetes, and Obesity 200916 10-15. (https://doi.org/10.1097/med.0b013e328320d54c)

52 Reinehr T, Kulle A, Wolters B, Lass N, Welzel M, Riepe F \& Holterhus PM. Steroid hormone profiles in prepubertal obese children before and after weight loss. Journal of Clinical Endocrinology and Metabolism 201398 E1022-E1030. (https://doi.org/10.1210/ jc.2013-1173)

53 Kumari M, Chandola T, Brunner E \& Kivimaki M. A nonlinear relationship of generalized and central obesity with diurnal cortisol secretion in the Whitehall II study. Journal of Clinical Endocrinology and Metabolism 201095 4415-4423. (https://doi.org/10.1210/jc.2009-2105)

54 Rubinow DR, Roca CA, Schmidt PJ, Danaceau MA, Putnam K, Cizza G, Chrousos G \& Nieman L. Testosterone suppression of CRH-stimulated cortisol in men. Neuropsychopharmacology 200530 1906-1912. (https://doi.org/10.1038/sj.npp.1300742)

$55 \mathrm{Wu} \mathrm{C}$, Wei K \& Jiang Z. 5Alpha-reductase activity in women with polycystic ovary syndrome: a systematic review and meta-analysis. Reproductive Biology and Endocrinology 201715 21. (https://doi. org/10.1186/s12958-017-0242-9)

56 Torchen LC, Idkowiak J, Fogel NR, O’Neil DM, Shackleton CH, Arlt W \& Dunaif A. Evidence for increased 5alpha-reductase activity during early childhood in daughters of women with polycystic ovary syndrome. Journal of Clinical Endocrinology and Metabolism 2016101 2069-2075. (https://doi.org/10.1210/jc.2015-3926)

57 Barat P, Livingstone DE, Elferink CM, McDonnell CR, Walker BR \& Andrew R. Effects of gonadectomy on glucocorticoid metabolism in obese Zucker rats. Endocrinology 2007148 4836-4843. (https://doi. org/10.1210/en.2007-0597)

58 Lax ER, Rumstadt F, Plasczyk H, Peetz A \& Schriefers H. Antagonistic action of estrogens, flutamide, and human growth hormone on androgen-induced changes in the activities of some enzymes of hepatic steroid metabolism in the rat. Endocrinology 1983113 1043-1055. (https://doi.org/10.1210/endo-113-3-1043)

59 Mode A \& Norstedt G. Effects of gonadal steroid hormones on the hypothalamo-pituitary-liver axis in the control of sex differences in hepatic steroid metabolism in the rat. Journal of Endocrinology 1982 95 181-187. (https://doi.org/10.1677/joe.0.0950181)

60 Tsuji M, Terada N, Yabumoto H, Takeyama M \& Matsumoto K. Hormonal regulation of activities of 4 -ene- 5 beta and 5 alphareductases and 17 beta-ol-dehydrogenase in immature golden hamster ovary. Journal of Steroid Biochemistry 198318 777-781. (https://doi.org/10.1016/0022-4731(83)90259-5)

61 Albiston AL, Smith RE \& Krozowski ZS. Sex- and tissue- specific regulation of 11 beta-hydroxysteroid dehydrogenase mRNA. Molecular and Cellular Endocrinology 1995109 183-188. (https://doi. org/10.1016/0303-7207(95)03501-w)

62 Miki K \& Sudo A. Effect of urine $\mathrm{pH}$, storage time, and temperature on stability of catecholamines, cortisol, and creatinine. Clinical Chemistry 199844 1759-1762. (https://doi.org/10.1093/ clinchem/44.8.1759)

63 van Keulen BJ, Dolan CV, Andrew R, Walker BR, Hulshoff Pol HE, Boomsma DI, Rotteveel J \& Finken MJJ. Long-term stability of cortisol production and metabolism throughout adolescence: longitudinal twin study. Twin Research and Human Genetics 202023 33-38. (https://doi.org/10.1017/thg.2020.6)

64 Ross KM, Murphy MLM, Adam EK, Chen E \& Miller GE. How stable are diurnal cortisol activity indices in healthy individuals? Evidence from three multi-wave studies. Psychoneuroendocrinology 201439 184-193. (https://doi.org/10.1016/j.psyneuen.2013.09.016)

Received in final form 23 March 2020

Accepted 15 May 2020

Accepted Manuscript published online 15 May 2020 https://ec.bioscientifica.com https://doi.org/10.1530/EC-20-0123
(C) 2020 The authors Published by Bioscientifica Ltd
This work is licensed under a Creative Commons Attribution-NonCommercial-NoDerivatives 4.0 International License.ifica com at $04 / 26 / 2023$ 09:41:02AM 